\title{
FEATURES OF METHANE RELEASE IN THE WING OF A MINE FIELD DURING MINING OF GAS-BEARING COAL SEAMS
}

\author{
E. Filatieva \\ Postgraduate student, Volodymyr Dahl East \\ Ukrainian National University, Ukraine
}

V. Sokolenko

Candidate of technical science, Associate Professor, Volodymyr Dahl East

Ukrainian National University, Ukraine

\author{
A. Oleynichenko \\ Postgraduate student, Volodymyr Dahl East \\ Ukrainian National University, Ukraine
}

\author{
M. Filatiev \\ Doctor of technical science, Associate Professor, \\ Volodymyr Dahl East \\ Ukrainian National University, Ukraine
}

\begin{abstract}
Nowadays, gas emission has been studied, in most cases, within separate extraction sites and preparatory mine workings. The process of gas emission outside the exploited extraction sites under the influence of displacement activation of the undermined coal and rock stratum have not been studied thoroughly. This is not reflected in the regulatory documents on the issues of predicting gas emission.

Methane release from the undermined sources within and outside the extraction sites is determined by the degree of the stope works development both at the exploited site and in the mine field wing under the influence of the mined-out space of the stopped longwall faces.

Methane release under the influence of rock displacement activation in some cases leads to unpredictable situations at present. They are conditioned by additional influx of an unpredictable gas amount and the lack of information about mine workings, where this gas emission is possible.

Monitoring of changes in gas emission in all mine workings and degassing wells has been conducted in the course of mining the extraction sites, from the beginning of their exploitation to the end of the stope work operations, as well as in the mine field wing. In full such observations have been conducted at "Gazeta Izvestia" Mine in the mine field wing when mining a gas-bearing anthracite seam. The total observa-
\end{abstract}


tion duration was 94 months. During this period, eleven extraction sites have been mined by panels to the rise.

The experimental data obtained made it possible to determine the patterns of changes in gas emission from the undermined coal and rock stratum within the exploited extraction sites and beyond their boundaries in the mine field wing.

Gas emission from the coal and rock stratum within the extraction site is directly proportional to the area of mined-out space, the total coal output from the extraction panel, the average daily coal output, and the average velocity of the stope face advance. The most convenient and intuitive parameter for determining the total amount of gas released from the undermined stratum within the extraction site and the average level of methane release is the specific gas emission per unit area of the minedout space.

Gas emission outside the exploited extraction site from the mined-out space of the stopped longwall faces does not occur in case of incomplete earth's surface undermining. When the complete earth's surface undermining is achieved, the ratio of gas emission within the extraction site to methane release from the mined-out space of the stopped longwall face directly proportionally depends on its dimensions.

Keywords: methane release, coal seams, mine workings, extraction site, mine field, stope workings, rock development, activation of displacement, mined-out space, area, specific gas emission.

Introduction. Until now, the change in methane release during the gas-bearing coal seams mining has been studied, in most cases, when exploiting the separate extraction sites. For this reason, absolute $\left(\mathrm{m}^{3} / \mathrm{min}\right)$ or relative gas emission $\left(\mathrm{m}^{3} /\right.$ ton $)$ for separate extraction sites and preparatory mine workings are considered as the main predicted values [1]. According to this regulatory document, methane release within the mine field (wing) is determined as the simple sum of gas emission into the mine workings of separate extraction sites and preparatory faces.

The main gas emission source in the overall gas balance of the mine is the stope workings. As a rule, their share is 90 percent or more. In turn, the predominant gas emission at the extraction site occurs from undermined coal seams and host rocks. Methane release from these sources to a considerable extent, other conditions being equal, depends on the degree of stope works development, both within the extraction site and the entire mine field [2]. Gas emission from undermined sources in the studied case depends on the rocks displacement processes under the influence of stope works and can occur both within the extraction site and beyond its boundaries into allmine workings. The main influencing factor of gas emission into all- 
mine workings is the displacement activation of the undermined coal and rock stratum. Methane release under the influence of rock displacement activation at a certain stage of the stope works development in the mine field can lead to unpredictable situations at present. They are conditioned by additional influx of an unpredictable gas amount and the lack of information about mine workings, where the methane release is possible under the influence of undermined rocks displacement activation. These circumstances are not taken into account by the current regulatory document [1] due to insufficient knowledge of gas emission from the undermined coal and rock stratum depending on the degree of the stope works development within the mine field boundaries. Research in this direction is relevant, since the effectiveness of measures for the safe development of gas-bearing coal seams, which help to reduce the accident rate in coal mines associated with outbreaks and explosions of methane-air mixture, largely depends on their results.

The purpose of this work is to determine the dependences of gas emission on influencing factors during the stope works development within the boundaries of the extraction site and the mine field on the basis of the experimental data of the extraction sites mining.

To achieve the purpose, the following tasks should be solved:

- in the course of mining the extraction sites in the mine field, the following is set for each of them: the length of the longwall face and the extraction panel, the area of the mined-out space, the total coal output during the period of site exploitation, the average daily coal output for the entire period, the average velocity of the stope face advance, the total amount of gas released, the average absolute and relative gas emission, the amount of gas released within the extraction site and beyond its boundaries;

- a change in the absolute and relative gas emission from influencing factors is determined in the course of mining the extraction sites in the mine field;

- a change in the nature of gas emission is analysed depending on the influencing factors within each extraction site and compared with similar dependences for the mine field wing.

The methodology provides for monitoring a change in gas emission into all mine workings of the mine field wing and degassing wells in the course of mining the extraction sites, from the beginning 
of their exploitation to the end of the stope work operations. Periodic measurements of methane flow rate in mine workings and degassing wells were conducted using portable devices every 1-5 days. Measurements in certain points of mine workings were duplicated by the readings of the automatic gas protection (AGP) service. In full such observations have been conducted at "Gazeta Izvestia" Mine of Donbasantratsyt, DP in the mine field wing when mining a gas-bearing anthracite seam $\ell_{2}^{6}$ with a thickness of $0.9 \mathrm{~m}$ in the mine field heaved area. The total observation duration was 94 months. During this period, eleven extraction sites have been mined by panels to the rise. The order of their mining and the mine field cutting was significantly affected by the presence of discontinuous geological faults (Karlovsky and Sofievsky faults). This influence consists in an increase in the natural gas content of the mined seam as it recedes from the discontinuous faults and the necessity to prepare for exploitation of the sites with different dimensions of longwall faces and mined-out extraction panels.

Main Body. The gas content of the mined seam at each extraction site significantly decreases with the stope faces removal from the face entries. This is caused by a decrease in the depth of mining and the approach of the stope faces to the flash gas zone of the anthracite seam when it is mined to the rise. For this reason, the analysis (Table 1) for each extraction site is based on the accepted average values of anthracite gas content between their indicators for face entries and stopped stope faces.

Table 1

Exploitation indicators of longwall faces during mining the seam $\ell_{2}^{6}$ at "Gazeta Izvestia" Mine

\begin{tabular}{c|c|c|c|c|c|c|c|c|c}
\hline \multirow{2}{*}{$\begin{array}{c}\text { Longwall } \\
\text { face }\end{array}$} & \multicolumn{3}{|c|}{$\begin{array}{c}\text { Mining-and-geological and mining-engineering conditions of } \\
\text { longwall faces mining }\end{array}$} & \multicolumn{3}{c}{ Exploitation indicators of extraction sites } \\
\cline { 2 - 12 } & $\begin{array}{l}\text { Distance } \\
\text { of the face } \\
\text { entry from } \\
\text { Sofievsky } \\
\text { fault, } \mathrm{m}\end{array}$ & $\begin{array}{l}\text { Average } \\
\text { natural } \\
\text { gas } \\
\text { content of } \\
\text { the mined } \\
\text { seam, } \\
\mathrm{m}^{3} / \text { t.g.m. }\end{array}$ & $\begin{array}{l}\text { Mined } \\
\text { panel } \\
\text { length, } \\
\mathrm{m}\end{array}$ & $\begin{array}{l}\text { Longwall } \\
\text { face } \\
\text { length, } \mathrm{m}\end{array}$ & $\begin{array}{l}\text { Mined- } \\
\text { out } \\
\text { space } \\
\text { area, } \\
\mathrm{m}^{2}\end{array}$ & $\begin{array}{l}\text { Total } \\
\text { coal } \\
\text { output, } \\
\text { thousand } \\
\text { tons }\end{array}$ & $\begin{array}{l}\text { Average } \\
\text { daily } \\
\text { coal } \\
\text { output, } \\
\text { tons }\end{array}$ & $\begin{array}{l}\text { Average } \\
\text { velocity } \\
\text { of the } \\
\text { stope } \\
\text { face } \\
\text { advance, } \\
\text { m/day }\end{array}$ & $\begin{array}{c}\text { Time } \\
\text { period of } \\
\text { mining the } \\
\text { extraction } \\
\text { site, days }\end{array}$ \\
\hline $\begin{array}{c}\text { 1st } \\
\text { western }\end{array}$ & 1 & 2 & 3 & 4 & 5 & 6 & 7 & 8 & 9 \\
\hline $\begin{array}{c}\text { 1st bis } \\
\text { western }\end{array}$ & between faults & 9.2 & 775 & 100 & 69924 & 153.6 & 180.3 & 0.8 & 913 \\
\hline $\begin{array}{c}\text { 2nd } \\
\text { western }\end{array}$ & 270 & 13.6 & 1186 & 200 & 237200 & 389.6 & 914.6 & 2.8 & 426 \\
\hline
\end{tabular}


Continuation of table 1

\begin{tabular}{c|c|c|c|c|c|c|c|c|c}
\hline 2nd bis western & 470 & 24.0 & 279 & 200 & 51598 & 78.4 & 197.5 & 0.7 & 397 \\
\hline 3rd western & 670 & 18.2 & 1559 & 215 & 335185 & 535.3 & 1099.1 & 3.2 & 487 \\
\hline 4th western & 885 & 21.9 & 1491 & 210 & 313110 & 493.8 & 1080.6 & 3.3 & 457 \\
\hline 5th western & 1095 & 23.4 & 1421 & 216 & 307922 & 492.8 & 1014.0 & 2.9 & 486 \\
\hline 6th western & 1311 & 25.4 & 1169 & 230 & 268870 & 472.6 & 819.0 & 2.0 & 577 \\
\hline 7th western & 1541 & 24.6 & 1309 & 230 & 301070 & 493.8 & 901.1 & 2.4 & 548 \\
\hline 8th western & 1741 & 31.0 & 787 & 215 & 169205 & 265.7 & 874.0 & 2.6 & 304 \\
\hline 9th western & 1956 & 34.8 & 329 & 250 & 82250 & 116.8 & 320.9 & 0.9 & 364 \\
\hline
\end{tabular}

Continuation of table 1

Exploitation indicators of longwall faces during mining the seam $\ell_{2}^{b}$ at "Gazeta Izvestia" Mine

\begin{tabular}{|c|c|c|c|c|c|c|c|c|c|c|c|c|}
\hline \multicolumn{6}{|c|}{ Information on gas emission } & \multicolumn{2}{|c|}{$\begin{array}{c}\text { Amount of gas released during } \\
\text { extraction site exploitation, } \\
\text { thous. m3 }\end{array}$} & \multirow{2}{*}{ 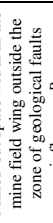 } & \multirow{2}{*}{ 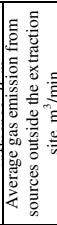 } & \multirow{2}{*}{ 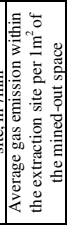 } & \multirow{2}{*}{ 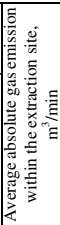 } & \multirow[b]{2}{*}{ zั } \\
\hline $\begin{array}{c}\text { Total } \\
\text { amount } \\
\text { of gas } \\
\text { released, } \\
\text { thousand } \\
\mathrm{m}^{3}\end{array}$ & $\begin{array}{c}\text { Average } \\
\text { absolute } \\
\text { gas } \\
\text { emission, } \\
\mathrm{m}^{3} / \mathrm{min}\end{array}$ & $\begin{array}{c}\text { Average } \\
\text { relative } \\
\text { gas } \\
\mathrm{emission}^{3} \\
\mathrm{~m}^{3} / \text { ton }\end{array}$ & \begin{tabular}{|c|} 
Average \\
gas \\
emission \\
per $1 \mathrm{~m}^{2}$ \\
of \\
mined- \\
out \\
space
\end{tabular} & $\begin{array}{c}\text { Maximum } \\
\text { gas } \\
\text { emission, } \\
\mathrm{m}^{3} / \mathrm{min}\end{array}$ & $\begin{array}{l}\text { Coefficient } \\
\text { of variation }\end{array}$ & $\begin{array}{l}\text { Within } \\
\text { the } \\
\text { extraction } \\
\text { site }\end{array}$ & $\begin{array}{l}\text { Outside the } \\
\text { extraction site }\end{array}$ & & & & & \\
\hline 10 & 11 & 12 & 13 & 14 & 15 & 16 & 17 & 18 & 19 & 20 & 21 & \\
\hline 4698.7 & 2.8 & 16.8 & 25.3 & 10.4 & 3.7 & 4698.7 & 0.0 & - & 0.0 & 25.3 & 2.8 & \\
\hline 2546.4 & 1.9 & 16.6 & 36.4 & 6.3 & 3.3 & 2546.4 & 0.0 & - & 0.0 & 36.4 & 1.9 & \\
\hline 13560.7 & 22.2 & 34.8 & 57.2 & 55.2 & 2.5 & 13560.7 & 0.0 & 200 & 0.0 & 57.2 & 22.2 & \\
\hline 4665.7 & 8.2 & 59.5 & 90.4 & 20.0 & 2.4 & 4665.7 & 0.0 & 200 & 0.0 & 90.4 & 8.2 & $\begin{array}{c}\text { Start of } \\
\text { exploitation } \\
\text { in the 3rd } \\
\text { western } \\
\text { longwall } \\
\text { ace has not } \\
\text { influenced } \\
\text { on gas } \\
\text { emission }\end{array}$ \\
\hline 16670.7 & 23.8 & 31.1 & 49.7 & 48.9 & 2.1 & 16670.7 & 0.0 & 415 & 0.0 & 49.7 & 23.8 & \\
\hline 15513.8 & 23.6 & 31.4 & 49.5 & 50.0 & 2.1 & 15513.8 & $616.9 *$ & 625 & 0.9 & 49.5 & 23.6 & $\begin{array}{c}\text { Start of } \\
\text { exploitation } \\
\text { of the 4th } \\
\text { western } \\
\text { longwall } \\
\text { cace has not } \\
\text { influenced } \\
\text { on a change } \\
\text { in gas } \\
\text { emission } \\
\end{array}$ \\
\hline 22042.2 & 31.5 & 44.7 & 71.6 & 57.0 & 2.3 & $\begin{array}{l}17093.4 \\
\end{array}$ & 4948.8 & 841 & 7.1 & 55.5 & \begin{tabular}{|l|}
24.4 \\
\end{tabular} & \\
\hline 23041.2 & 27.7 & 48.8 & 85.7 & 66.0 & 2.4 & 16407.2 & 6634.0 & 1071 & 8.0 & 61.0 & 19.7 & \\
\hline 16407.2 & 20.8 & 33.2 & 54.5 & 56.7 & 2.7 & 16407.2 & - & 1301 & - & 54.5 & 20.8 & \\
\hline 12764.6 & 29.2 & 48.0 & 75.4 & 80.0 & 2.7 & 6918.4 & 5846.2 & 1516 & 13.4 & 40.9 & 15.8 & \\
\hline 8911.6 & 17.0 & 76.3 & 108.3 & 29.0 & 1.7 & 3843.3 & 5068.3 & 1766 & 9.7 & 46.7 & 7.3 & \\
\hline
\end{tabular}

* - gas emission into wells at the site of the 3rd western longwall face

\section{Analysis of the experimental and calculated parameters}

Proceeding from the initial mining-and-geological conditions of the seam $\ell_{2}^{\beta}$, the $2^{\text {nd }}$ western longwall face was the first prepared by mining operations. In the course of its placement, it was assumed that the subsequent prepared extraction sites $\left(2^{\text {nd }}\right.$ bis, $3^{\text {rd }}, 4^{\text {th }}, 5^{\text {th }}, 6^{\text {th }}, 7^{\text {th }}$, $8^{\text {th }}$ and $9^{\text {th }}$ western longwall faces) with the stope works development in the mine field wing, will be located outside the zone of geological faults influence.

The coal reserves mining in close proximity to geological faults was initially carried out by the $1^{\text {st }}$ western longwall face. Then, due to 
another geological fault, located approximately in the middle of the extraction site, it was divided into two parts, which have formed the $1^{\text {st }}$ and $1^{\text {st }}$ bis western longwall faces, $100 \mathrm{~m}$ long each, respectively. The rest data on the extraction sites exploiting conditions are given in Table 1, and the order of mining the longwall faces, including their joint exploitation - in Table 2. The schedule for commissioning the longwall faces and their decommissioning over time is shown in Fig. 1 .

According to the plan for stope works development, the main (supporting) longwall faces are the $2^{\text {nd }}, 3^{\text {rd }}, 4^{\text {th }}, 5^{\text {th }}, 6^{\text {th }}, 7^{\text {th }}, 8^{\text {th }}$ and $9^{\text {th }}$ western ones, which were planned to mine sequentially with a load about 1000 tons/day. Such a plan has been actually implemented at these extraction sites (Table 1). The exception is the $9^{\text {th }}$ western longwall face, during mining of which the indicated load was provided only in the first months of its operation. Then, due to the worsening of mining-and-geological conditions (roof rocks fall and blockages of the longwall face work space), coal mining has decreased significantly. The average daily coal output for the entire period of the extraction site exploitation amounted to 320.9 tons.

The rest mining sites $\left(1^{\text {st }}, 1^{\text {st }}\right.$ bis and $2^{\text {nd }}$ bis western longwall faces) were planned to mine with an average daily load of about 200 tons/day. Their main goal was to perform a more complete extraction of coal reserves, including near geological faults.

Table 2

Information about the sequence and duration of extraction sites joint exploitation during

mining the anthracite seam $\ell_{2}^{b}$ at "Gazeta Izvestia" Mine in the mine field heaved area

\begin{tabular}{|c|c|c|c|c|c|c|c|c|}
\hline \multirow{2}{*}{$\begin{array}{l}\text { Longwall face, } \\
\text { mine field } \\
\text { wing }\end{array}$} & \multirow{2}{*}{$\begin{array}{l}\text { Exploitation } \\
\text { period, month, } \\
\text { year }\end{array}$} & \multirow{2}{*}{$\begin{array}{l}\text { Sequence of longwall } \\
\text { faces commissioning }\end{array}$} & \multirow{2}{*}{$\begin{array}{l}\text { Maximum number of } \\
\text { longwall faces in operation } \\
\text { in certain periods of time }\end{array}$} & \multicolumn{4}{|c|}{$\begin{array}{l}\text { Number of exploited longwall } \\
\text { faces and periods of their joint } \\
\text { operation, month }\end{array}$} & \multirow{2}{*}{$\begin{array}{l}\text { Period of extraction } \\
\text { sites exploitation, } \\
\text { month }\end{array}$} \\
\hline & & & & 1 & 2 & 3 & 4 & \\
\hline 1st western & I.1981-III1984 & 5 & 4 & - & 8 & 15 & 16 & 39 \\
\hline 1 st bis western & XII1981-XX1984 & 6 & 4 & - & 1 & 16 & 17 & 34 \\
\hline 2nd western & IX1978-X1979 & 1 & 2 & 12 & 2 & - & - & 14 \\
\hline $\begin{array}{ll}\begin{array}{l}\text { 2nd } \\
\text { western }\end{array} & \text { bis } \\
\end{array}$ & III 1980-IV.1981 & 3 & 3 & - & 8 & 6 & - & 14 \\
\hline 3rd western & VIII1979-XI1980 & 2 & 3 & 4 & 9 & 2 & - & 15 \\
\hline 4th western & X1980-XII1981 & 4 & 4 & - & 8 & 6 & 1 & 15 \\
\hline 5th western & XII1981-III1983 & 6 & 4 & - & - & 11 & 5 & 16 \\
\hline 6th western & XII1982-VI1984 & 7 & 4 & - & 1 & 2 & 16 & 19 \\
\hline 7th western & IV.1983-X1984 & 8 & 4 & - & - & 5 & 12 & 17 \\
\hline 8th western & V.1984-I.1985 & 9 & 4 & 5 & - & 3 & 1 & 9 \\
\hline 9th western & V.1985-VI1986 & 10 & 1 & 13 & - & - & - & 13 \\
\hline $\begin{array}{ll}\begin{array}{l}\text { Mine } \\
\text { wing }\end{array} & \text { field } \\
\end{array}$ & IX1978-VI 1986 & - & $1-4$ & 34 & 37 & 66 & 68 & 94 \\
\hline
\end{tabular}




\begin{tabular}{|c|c|c|c|c|c|c|c|c|c|}
\hline \multirow{2}{*}{ Lawa } & \multicolumn{9}{|c|}{ Years of extraction sites exploitation } \\
\hline & 1978 & 1979 & 1980 & 1981 & 1982 & 1983 & 1984 & 1985 & 1986 \\
\hline 1st western & & & & & 39 months & & - & & \\
\hline 1st bis & & & & & & 34 months & & & \\
\hline western & & & & & & & & & \\
\hline 2nd western & & 14 months & & & & & & & \\
\hline $\begin{array}{l}\text { 2nd bis } \\
\text { westem }\end{array}$ & & & 14 months & & & & & & \\
\hline 3 rd western & & - & 16 months & & & & & & \\
\hline 4 th western & & & & 15 months & & & & & \\
\hline Sth western & & & & & 16 months & - & & & \\
\hline 6th western & & & & & & 17 month & _ & & \\
\hline 7 th western & & & & & & 18 months & & & \\
\hline 8th westem & & & & & & & 10 months & & \\
\hline 9th western & & & & & & & & 14 months & \\
\hline
\end{tabular}

Fig. 1. Schedule for extraction sites exploitation at "Gazeta Izvestia" Mine during mining the seam $\ell_{2}^{B}$ in the mine field heaved area

The rock displacement activation is related both to the stope works development within the extraction site boundaries, and within the mine field.

The obtained experimental data make it possible to assess the tendency of a change in gas emission outside the extraction site from the undermined coal and rock stratum, when the rock displacement is activated with the stope works development in the mine field wing.

To determine the general trend of gas emission under the influence of the degree of stope works development in the mine field, the changes have been studied in the total amount of gas $\Sigma I$, released in the course of mining the separate extraction sites (Fig. 2).

The analysis involved the results of mining all the extraction sites, except for the $1^{\text {st }}$ and $1^{\text {st }}$ bis western longwall faces.

This is due to the fact that they were located in the immediate zone of geological faults influence and according to exploiting conditions, differed significantly from other longwall faces (host rocks disturbance, gas content of coal, volume of coal output and velocity of stope faces advance, etc.) (Table1). 


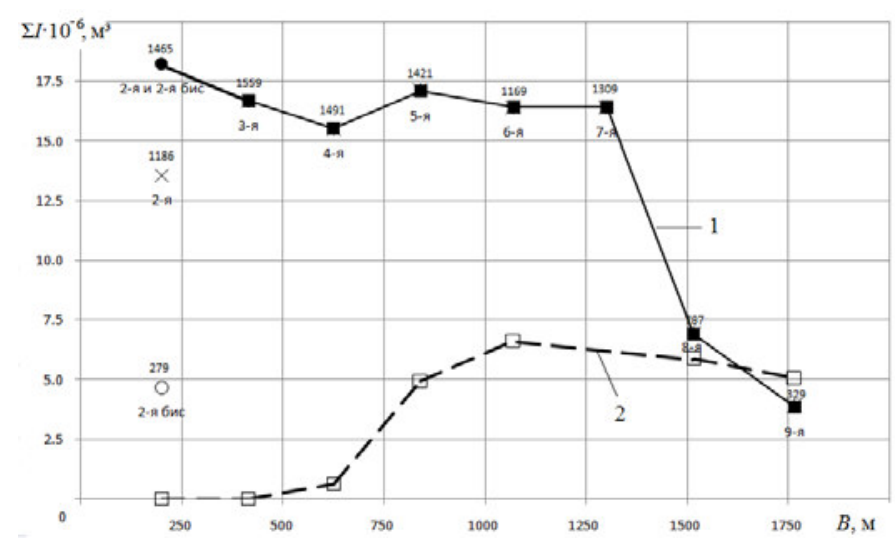

Fig. 2. Dependence of the amount of gas released $(\Sigma \mathrm{I})$ on the width of the minedout space $(B)$ outside the zone of geological faults influence in the mine field heaved area of "Gazeta Izvestia" Mine

1,2 - curves of changes in the amount of gas released from the undermined coal and rock stratum, within the extraction sites and beyond their boundaries, respectively; ${ }_{3-\Omega}^{+5}, \square-$ - experimental gas emission data within and outside the extraction sites under the influence of activation of the undermined coal and rock stratum displacement, respectively (a digit above - the panel length (m), below - the number of longwall face);,$\times, \bullet$ - experimental data on gas emission within the $2^{\text {nd }}$ bis and $2^{\text {nd }}$ western longwall faces with the extraction panels length of 279 and $1186 \mathrm{~m}$., respectively, and their total length of 1465 m.

The extraction panel of the $2^{\text {nd }}$ western longwall face with a length of $1186 \mathrm{~m}$ was the first to be partially mined in the mine field wing, and then it was completely finalized by the $2^{\text {nd }}$ bis western longwall face with the extraction panel length of $279 \mathrm{~m}$ (Table 1, Fig.2). The total length $(1465 \mathrm{~m})$ of the panel mined by these longwall faces was accepted to analysis.

Based on the mined panels length, the extraction sites were divided into two groups that differ from each other. The first group includes longwall faces, the length of extraction panels of which is in the range of 1169-1559 meters, and the second group involves the extraction panels of the $8^{\text {th }}$ and $9^{\text {th }}$ western longwall faces. The length 
of their extraction panels is 787 and 329 meters, respectively. Besides the extraction panels length, the longwall faces of the first group have a higher load on the stope faces. For the $2^{\text {nd }}, 3^{\text {rd }}, 4^{\text {th }}, 5^{\text {th }}, 6^{\text {th }}$ and $7^{\text {th }}$ western longwall faces, the average daily coal output (for the entire exploitation period) was 819.0-1099.1 tons, and the total amount of coal mined for each extraction panel was in the range of $468.0 \div 535.3$ thousand tons. These indicators are significantly different for the longwall faces of the second group. The total coal output from the $8^{\text {th }}$ western longwall face amounted to 265.7 thousand tons with an average daily output -874.0 tons, and for the $9^{\text {th }}$ western longwall face these indicators were 116.8 thousand tons at 320.9 tons/day, respectively.

To set a general trend of a change in the gas emission amount within the extraction sites and beyond their boundaries, the influence has been studied on these parameters of a change in the dimensions of the mined-out space $(B)$ in the course of mining the extraction panels in the mine field wing (Fig. 2).

The shorter lengths in the longwall faces extraction panels of the second group (the $8^{\text {th }}$ and $9^{\text {th }}$ ) significantly affected the decrease in the amount of methane released within the extraction sites. For the first group longwall faces, with panels lengths of 1169-1559 m, 15.5-18.2 million $\mathrm{m}^{3}$ of methane evolved. When mining the longwall faces of the second group, with panels lengths of 329-787 m, only 3.8-6.9 million $\mathrm{m}^{3}$ of gas evolved (Table 1, Fig.2).

Experimental data evidence that in addition to coal output, the extraction panels dimensions influence the amount of gas released from the undermined coal and rock stratum within the extraction sites. They are fully determined by the length of the panel and the length of the longwall face. The most integral parameter for characterizing the extraction panel in this case is the area of its mined-out space. This is confirmed by a close correlational directly proportional dependence of the amount of gas released within the extraction sites on the mined-out spaces area $(r=0.97)$ for the first group of longwall faces (Fig.3). The length of the mined-out panels $\left(L_{\text {ст }}\right)$ is in the range of 279-1559 m, and the length of the longwall faces - in the range of 200-250 m. A high correlation coefficient of the dependence between the parameters $\Sigma I$ and $S$ evidences an approximate constancy of gas 
emission per unit area of the mined-out space $\left(\Sigma I_{y} / S\right)$ under identical mining-and-geological conditions. This indicates that the parameter $\Sigma I_{y} / S$, with an additional substantiation, can be an initial value for predicting the total amount of gas released from the undermined coal and rock stratum within each extraction panel. For the longwall faces group under study, the average value is $\Sigma I_{y} / S=56.2 \mathrm{~m}^{3} / \mathrm{m}^{2}$ (Fig. 3).

The areas of mined-out spaces at the mined-out extraction sites directly or indirectly depend on the parameters $\left(\bar{A}, \Sigma A, L_{\Omega}, \bar{v}_{o \psi}\right)$.

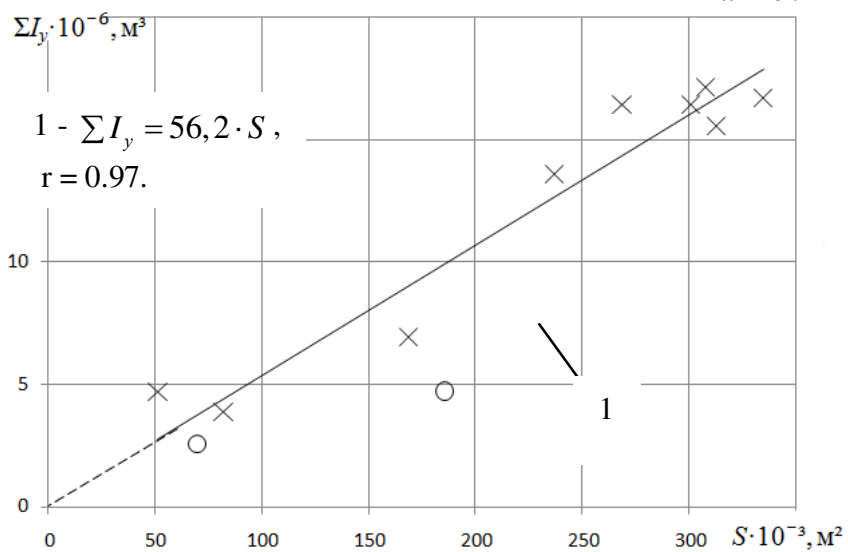

Fig.3. Dependence of the amount of gas $\left(\Sigma I_{y}\right)$ released within the extraction sites of "Gazeta Izvestia" Mine on the area of their mined-out spaces $(S)$

1 - averaging line for longwall faces located outside the zone of geological faults; $r$ - correlation coefficient; $\times$ - experimental data for longwall faces $\left(2^{\text {nd }}, 2^{\text {nd }}\right.$ bis, $\left.3^{\text {rd }}, 4^{\text {th }}, 5^{\text {th }}, 6^{\text {th }}, 7^{\text {th }}, 8^{\text {th }}, 9^{\text {th }}\right)$ outside the zone of influencing discontinuous geological faults; $\bigcirc$ - experimental data for longwall faces $\left(1^{\text {st }}\right.$ and $1^{\text {st }}$ bis) near geological faults.

The product of the longwall face length $L_{\Omega}$ by the extraction panel length $L_{\text {ст }}$ functionally corresponds to the mined-out space area $S$. The average velocity of the stope face advance $\left(\bar{v}_{{ }_{\nu}}\right)$ determines the period of mining the extraction panel of a length $\left(L_{\text {ст }}\right)$, with the longwall face length $L_{\mathrm{J}}$, and the total coal output $\Sigma A$ depends on the area of mined-out space $S$. The listed parameters are interdependent, and they determine both the total amount of gas released from the undermined coal and rock stratum within the extraction site $\Sigma I_{y}$, and 
the average gas emission $\bar{I}$ for the period of mining the extraction panel. Given the foregoing, the link of parameters has been studied (Fig.4). The total coal output from the extraction panel $\Sigma A$ is almost functionally $(r=0.99)$ related to the area of mined-out space $(S)$. The empirical coefficient 1.622 of equation 1 by its nature characterizes the seam efficiency with a thickness of $0.9 \mathrm{~m}$ (Fig. $4 a$ ). Similarly, with a high direct proportional correlational dependence $(r=0.98)$, the average daily coal output $\bar{A}$ is determined by the average daily velocity $\bar{v}_{о ч}$ of the stope face advance (Fig.46).
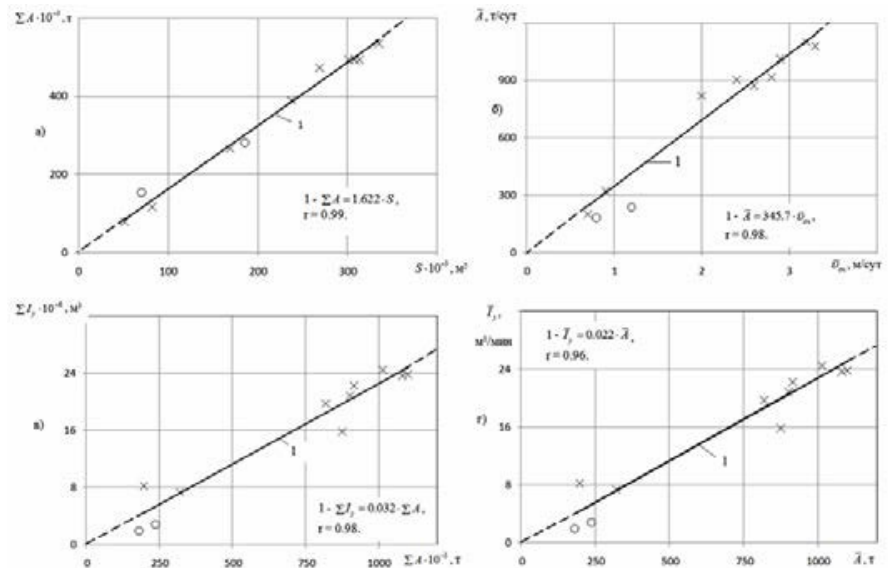

Fig. 4. Dependences between the parameters determining the total amount of gas $(\Sigma I)$ and its average value $(\bar{I})$ within the extraction sites of "Gazeta Izvestia" Mine

a) dependence of coal $\Sigma A$, mined at the extraction sites, on the area of mined-out space $S$; b) the link between the average daily coal output $\bar{A}$ with the average velocity $\left(\bar{v}_{o u}\right)$ of the stope faces advance; c) dependence of the amount of gas released within the extraction sites $\Sigma I_{y}$ on the mined coal amount $\Sigma A$; d) the influence of the average daily coal output $\bar{A}$ on the level of average gas emission from the undermined coal and rock stratum $\bar{I}_{y}$ within the extraction sites;

1 - averaging lines; $r$ - correlation coefficients; $\times, \circ$ - experimental data obtained outside and within the zone of geological faults influence. 
With high reliability $(r=0.98)$, the total coal output $(\Sigma A)$ determines the total amount of gas $\left(\Sigma I_{y}\right)$ released within the extraction site from the undermined coal and rock stratum (Fig.46).

The average daily absolute gas emission $\bar{I}$ directly proportionally depends $r=0.96$ on the average daily load $\bar{A}$ on the stope faces (Fig. 42 ), as well as on the average velocity $\bar{v}_{о ч}$ of their stope faces advance $r=0.93$. This confirms that a change in $\bar{A}$ and $\bar{v}_{o y}$ in the same proportion influences on the change of $\bar{I}$.

\section{The results of experimental data processing}

To obtain more reliable results, when determining the calculated (predicted) values $\Sigma I_{y}$ and $\bar{I}_{y}$, it is necessary to proceed, in our opinion, from the projected extraction panel area $(S)$. In this case, the errors are excluded, caused by the determination of $\Sigma A$ with the use of the mined seam efficiency and $\bar{A}$, the average velocity $\left(\bar{v}_{o y}\right)$ of the stope face advance and the exploited longwall face length $\left(L_{\Omega}\right)$.

Such a proposal is supported by the following arguments:

- an assumed area $S$ of mining the extraction panel is sufficiently reliably determined by the simple lengths product of the longwall faces and extraction panels;

- it is directly visible the physical significance of the ongoing processes associated with gas emission from the undermined coal and rock stratum, as well as with the processes of its possible displacement activation;

- under otherwise equal mining-and-geological conditions, according to the experience of mining one extraction site, the specific gas emission $\left(\Sigma I_{y} / S\right)$ is set per unit area of the mined-out space. This can be used to predict gas emissions when mining the subsequent extraction sites, which are developed with other parameters $L_{\mathrm{cT}}, L_{\mathrm{J}}, \bar{v}_{\text {оч }}, \Sigma A$ and $\bar{A}$.

An integral part of the gas emission from the undermined coal and rock stratum is methane release outside the extraction sites (panels) under the influence of the stope works development in the mine field and the rock displacement activation. Depending on the ventilation schemes used, gas emission in this case can occur both within the 
boundaries of the extraction sites and beyond them into all-mine workings (Table 1, Fig.2).

Unlike gas emission within the extraction sites $\left(\Sigma I_{y}, \bar{I}_{y}\right)$, methane release beyond their boundaries from the mined-out space of the stopped longwall faces $\left(\sum I_{b}, \bar{I}_{b}\right)$, at first glance, does not depend on the area of the mined-out space of extraction panels $S$, total $\Sigma A$ and average daily coal output $\bar{A}$, as well as the velocity $\bar{v}_{o u}$ of the stope face advance (Fig. 5). The correlation coefficients $r$ between the specified parameters are in the range of $0,10-0,17$, which indirectly indicates the absence of any link between the studied parameters. This fact indicates a different mechanism of the gas emission process from the undermined coal and rock stratum within the exploited site and beyond its boundaries from the mined-out space of stopped longwall faces. This also indicates the influence of other factors that are more significant in this case. Such factors are obviously associated with the stope works development within the entire mine field wing and the manifestation of the rock displacement activation processes.
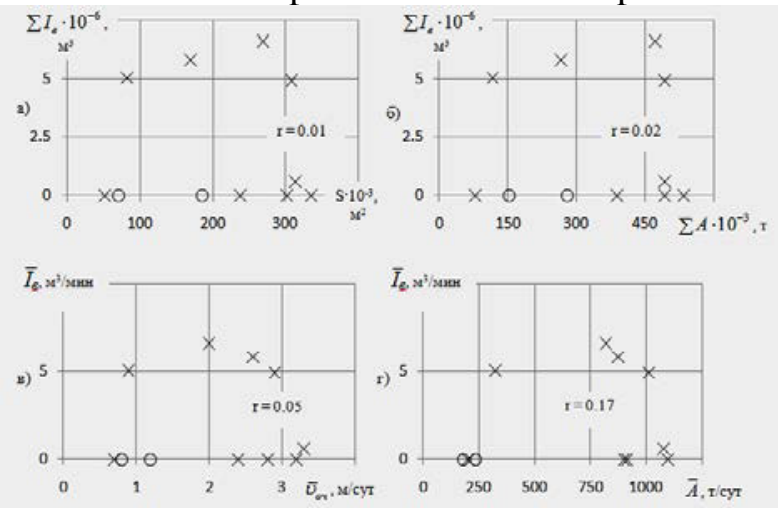

Fig. 5. Influence of some parameters on the total amount of gas released $\left(\Sigma I_{6}\right)$ and its average level $\left(\bar{I}_{b}\right)$ outside the extraction sites (from the mined-out spaces of the stopped longwall faces) at "Gazeta Izvestia" Mine

a) and б) the influence of the area $(S)$ of the extraction sites mined-out spaces and coal output $(\Sigma A)$ on the amount of gas released $\Sigma I_{b}$, respectively; в) and $\Gamma$ ) the influence of the average velocity $\bar{v}_{{ }^{4}}$ 
of the stope faces advance and average daily coal output $\bar{A}$ on the average gas emission outside the extraction sites $\bar{I}_{b}$, respectively; $r$ correlation coefficient; $\times, \circ$ - experimental data obtained outside and within the zone of geological faults influence, respectively.

The parameters of gas emission $\left(\Sigma I_{y}, \bar{I}_{y}\right)$ within the exploited extraction site depend on the stope works development within its boundaries and factors characterizing the conditions and regime of coal mining $\left(S, \Sigma A, \bar{A}, \bar{v}_{\text {оч }}\right)$.

An analysis of the gas emission process from the mined-out space of the stopped longwall faces indicates (Table 1, Fig. 2) that it begins to occur with some stope works development in the mine field wing. Significant level and volume of gas emission $\left(\bar{I}_{6}=0.9 \mathrm{~m}^{3} / \mathrm{min}\right.$ and $\Sigma I_{B}=0.6$ million $\mathrm{m}^{3}$ ) were revealed during the $4^{\text {th }}$ western longwall face exploitation, when the dimension (width) of the mined-out space of the stopped longwall faces was $415 \mathrm{~m}$ (Table 3 ). When exploiting the subsequent longwall faces $\left(5^{\text {th }}, 6^{\text {th }}\right.$ and $7^{\text {th }}$ conjugated, $\left.8^{\text {th }}, 9^{\text {th }}\right)$, the amount of gas released from the mined-out space of the stopped longwall faces $\Sigma I_{b}$ has increased and was in the range of 4.9-6.6 million $\mathrm{m}^{3}$ with an average value of 5.6 million $\mathrm{m}^{3}$. The general nature of a change in $\Sigma I_{B}$ depending on the degree of stope works development in the mine field depended on the ratio of the parameter $B-L_{\mathrm{J}}$ to the depth $H$ of mining operations. A high correlation ratio $(r=0.97)$ of such a dependence (Fig. $6 a$ ) evidences a non-random link between the studied parameters.

Table 3

Information on the total amount of gas $\left(\Sigma I_{B}\right)$ released outside the exploited sites (from the mined-out spaces of completed longwall faces) and its average level $\left(I_{B}\right)$

\begin{tabular}{|c|c|c|c|c|c|c|c|c|c|c|}
\hline \multirow[b]{2}{*}{$\begin{array}{l}\text { Longwall } \\
\text { face }\end{array}$} & \multirow{2}{*}{$\begin{array}{c}\text { Longwall } \\
\text { face } \\
\text { length, } \\
L_{l}, \mathrm{~m}\end{array}$} & \multirow{2}{*}{$\begin{array}{c}\text { Total } \\
\text { width of } \\
\text { mined- } \\
\text { out space } \\
, B, \mathrm{~m}\end{array}$} & \multirow{2}{*}{$\begin{array}{c}\text { Width of } \\
\text { mined-out } \\
\text { space of } \\
\text { completed } \\
\text { longwall } \\
\text { faces, } B \text { - } \\
L_{l}, \mathrm{~m}\end{array}$} & \multirow[b]{2}{*}{$\begin{array}{c}B-L_{\Omega} \\
\mathrm{H}\end{array}$} & \multicolumn{2}{|c|}{\begin{tabular}{|c|} 
Gas emission \\
within the exploited \\
site \\
\end{tabular}} & \multicolumn{2}{|c|}{\begin{tabular}{|c|} 
Gas emission \\
outside the \\
exploited site \\
\end{tabular}} & \multirow{2}{*}{$\begin{array}{c}\sum I_{B} \\
\sum I_{y} \\
\text { fractions }\end{array}$} & \multirow{2}{*}{$\begin{array}{c}\frac{\bar{I}_{b}}{\bar{I}_{y}} \\
\text { fractions }\end{array}$} \\
\hline & & & & & $\begin{array}{c}\sum I_{y} \cdot 10^{-6} \\
\mathrm{~m}^{3}\end{array}$ & $\left|\begin{array}{c}\bar{I}_{y} \\
\mathrm{~m}^{3} / \mathrm{min}\end{array}\right|$ & ${ }^{5 I_{6} \cdot 10}$ & $\begin{array}{c}\bar{I}_{\theta} \\
\mathrm{m}^{3} / \mathrm{min}\end{array}$ & & \\
\hline $\begin{array}{l}\text { 4th } \\
\text { western }\end{array}$ & 210 & 625 & 415 & 1.38 & 15.5 & 23.6 & 0.6 & 0.9 & 0.04 & 0.04 \\
\hline $\begin{array}{l}\text { 5th } \\
\text { western }\end{array}$ & 216 & 841 & 625 & 2.08 & 17.1 & 24.4 & 4.9 & 7.1 & 0.29 & 0.29 \\
\hline
\end{tabular}




\begin{tabular}{l|c|c|c|c|c|c|c|c|c|c}
\hline $\begin{array}{l}\text { 6th } \\
\text { western }\end{array}$ & 230 & 1071 & 841 & 2.80 & 16.4 & 19.7 & 6.6 & 8.0 & 0.40 & 0.41 \\
\hline $\begin{array}{l}7 \text { th } \\
\text { western }\end{array}$ & 230 & 1301 & 1071 & 3.57 & 16.4 & 20.8 & - & - & - & - \\
\hline $\begin{array}{l}\text { 8th } \\
\text { western }\end{array}$ & 215 & 1516 & 1301 & 4.34 & 6.9 & 15.8 & 5.8 & 13.4 & 0.84 & 0.85 \\
\hline $\begin{array}{l}9 \text { th } \\
\text { western }\end{array}$ & 250 & 1766 & 1516 & 5.05 & 3.8 & 7.3 & 5.1 & 9.7 & 1.34 & 1.33 \\
\hline
\end{tabular}

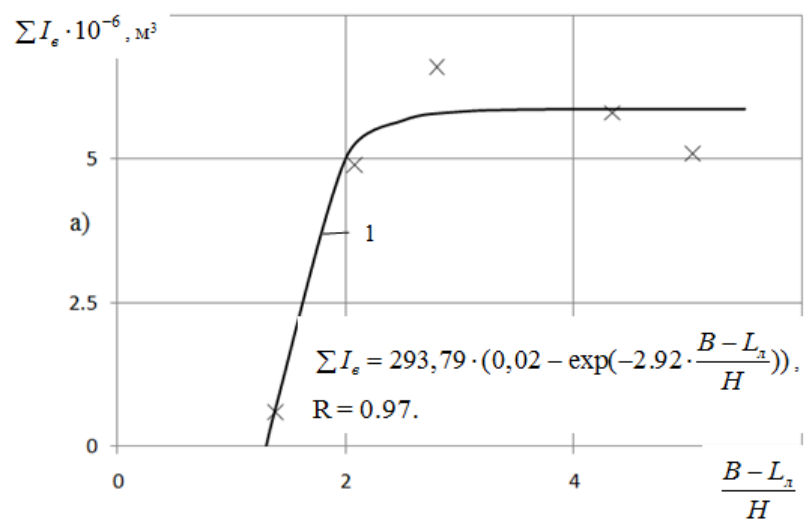

Fig. 6. Dependence of the total amount of gas $\left(\Sigma I_{b}\right)$, released outside the extraction sites (a) and its ratio with the amount of gas $\left(\Sigma I_{y}\right)$, released within the extraction sites (б) on the degree of the stope works development $\left.\left(B-L_{\mathrm{J}}\right) / H\right)$ in the mine field

1 - averaging curve and line; $R$ and $r$ - correlation ratio and correlation coefficient, respectively; $\mathrm{x}$ - experimental data; $B$ and $L_{n}$ - the total mined-out space dimension and the exploited longwall face length, respectively; $H=300 \mathrm{~m}$ - average depth of conducted stope works.

The experimental data (Table 3) also made it possible to set a ratio of gas emission from the mined-out space of the stopped longwall faces $\Sigma I_{b}$ to methane release within the exploited extraction site $\Sigma I_{y}$, depending on the degree of stope works development in the mine field $\left.\left(B-L_{\pi}\right) / H\right)$. This ratio in the studied mining-and-geological conditions varied from zero (when $\left.\left.\left(B-L_{\mathrm{J}}\right) / H\right) \leq 1.4\right)$ and reached the value of $1.34\left(\right.$ when $\left.\left.\left(B-L_{\mathrm{N}}\right) / H\right)=5.05\right)$. The obtained dependence (Fig. 6б) evidences that gas emission from the mined-out space of the stopped longwall faces begins to occur when the degree of undermining of the coal and rock stratum is more than 1.4 , which corresponds to the 
complete undermining of the earth's surface according to the regulatory document [3].

Conclusions. The studies performed made it possible to draw the conclusions that have important scientific-practical importance for ensuring safe conditions in coal mines relative to the gas factor:

- gas emission from the coal and rock stratum within the exploited extraction site directly proportionally depends on the area of the mined-out seam $S$, the total coal output from the extraction panel $(\Sigma A)$, the average daily coal output $\bar{A}$ and the average velocity of the stope face advance $\bar{v}_{o u}$. The correlation coefficients for these dependences were in the range of 0.95-0.99;

- the most convenient and intuitive parameter for determining the total amount of gas $\Sigma I$, released from the undermined stratum within the extraction site and the average level of methane release $\bar{I}$ is the specific gas emission per unit area $S$ of the mined-out space $(\Sigma I / S)$. This does not exclude the possibility of using other parameters $\left(\Sigma A, \bar{A}, \bar{v}_{\text {оч }}\right)$;

- with incomplete undermining of the earth's surface and coal and rock stratum, gas emission from the mined-out space of the stopped longwall faces outside the exploited extraction site is almost equal to zero;

- gas emission from the mined-out space of the stopped longwall faces is possible with the degree of the earth's surface undermining equal to ( $B$ $\left.\left.L_{\pi}\right) / H\right) \geq 1.4$ );

- the ratio of gas emission within the extraction site $\left(\Sigma I_{y}\right)$ to methane release from the mined-out space of the stopped longwall faces $\left(\Sigma I_{B}\right)$ directly proportionally depends on the parameter $\left.B-L_{\mathrm{N}}\right) / H$. With a sufficient degree of stope works development in the mine field $\left(B-L_{\mathrm{J}}\right) / H>2 \Sigma I_{B}$ can significantly exceed $\Sigma I_{y}$. Such an excess is most probable at low rates of the exploited site development.

References

1. Yanko S.V. (1994). Rukovodstvo po proektirovaniyu ventilyacii ugol'nyh shaht. Kiev:Osnova.

2. Filatiev M.V., Antoshchenko N.I., Dubovik A.I. (2017). Geomekhanicheskie processy sdvizheniya podrabotannyh porod i obosnovanie metodiki prognoza gazovydeleniya v ugol'nyh shahtah. Lisichansk:DonSTU.

3. Pravila pidrobki budivel', sporud i prirodnih ob'ektiv pri vidobuvanni vugillya pidzemnim sposobom. (2004). GSTU 101.00159226.001.2003. Kiev:(Galuzevij standart Ukraïni). 